\title{
Influence of skeletal muscle mass on graft regeneration after living-donor liver transplantation
}

\author{
Deniz Uluk, Johann Pratschke, Georg Lurje \\ Department of Surgery, Campus Charité Mitte I Campus Virchow-Klinikum, Charité - Universitätsmedizin Berlin, Berlin, Germany \\ Correspondence to: Georg Lurje, MD, Attending HPB and Transplant Surgeon. Department of Surgery, Charité - Universitätsmedizin Berlin, Campus \\ Charité Mitte I Campus Virchow-Klinikum, Augustenburger Platz 1, 13353 Berlin, Germany. Email: georg.lurje@charite.de. \\ Comment on: Pravisani R, Soyama A, Ono S, et al. Is there any correlation between liver graft regeneration and recipient's pretransplant skeletal \\ muscle mass?-a study in extended left lobe graft living-donor liver transplantation. Hepatobiliary Surg Nutr 2020;9:183-94.
}

Submitted May 19, 2021. Accepted for publication Jun 03, 2021.

doi: 10.21037/hbsn-21-202

View this article at: https://dx.doi.org/10.21037/hbsn-21-202

Body composition (BC) is defined as the relative proportion of fat, water, protein, and mineral components in the body and varies greatly among individuals. While skeletal muscle depletion is frequently seen in severely ill patients, sarcopenia, defined as a pathological reduction of skeletal muscle mass (SMM) and strength, is one of the most significant features of the metabolic imbalance related to end stage liver disease (ESLD). Accordingly, the assessment of BC was recently implemented in the European Association for the Study of the Liver (EASL) and American Association for the Study of Liver Diseases (AASLD) practice guidelines on nutrition in chronic liver disease. While sarcopenia was linked to clinical outcomes in a large variety of medical conditions, the prognostic value of muscle quality (muscle density or myosteatosis) over muscle quantity (SMM or sarcopenia) was recently identified by our group as a prognostic marker in deceased donor liver transplantation (LT) $(1,2)$.

Over the last decades, the global prevalence of organ shortage and waiting list mortality has prompted physicians to transplant an increasing amount of extended criteria donor (ECD) allografts $(3,4)$. An alternative strategy to address the problem of organ shortage is the implementation of living-donor liver transplantation (LDLT). In this scenario, ongoing liver graft regeneration represents a crucial process aiming at normalizing portal hypertension associated small-for-size syndrome and to meet metabolic and biosynthetic requirements of the recipient. As such, anabolic graft regeneration may also depend on the adequate availability of energy and metabolites (5).

In a recent article by Pravisani et al., the authors investigated the effects of loss of SMM as assessed preoperatively on computed tomography (CT) at L3 level on the graft regeneration rate (GRR) in 106 consecutive patients undergoing LDLT. While low SMM and sarcopenia are well known prognostic factors in patients undergoing whole-organ LT, little is known on BC-assessment and its impact on the GRR in the setting of LDLT. As such, the authors analyzed CT-images form 106 LDLT patients using the Synapse Vincent imaging processing software (Fujifilm, Tokyo, Japan). In brief, the third lumbar vertebra skeletal muscle index (L3-SMI) was expressed as cross-sectional muscle area/height, and the cut-off for a diagnosis of low muscle mass was L3-SMI $<42 \mathrm{~cm}^{2} / \mathrm{m}^{2}$ for men and L3-SMI $<38 \mathrm{~cm}^{2} / \mathrm{m}^{2}$ for women, according to recommendations of the Japanese Society of Hepatology. The study population showed a male-to-female ratio of 43:63 with a median BMI of 22.9 (20.8-26.5), and a mean pre-LT SMI of 47.2 \pm 9.1 and $39.1 \pm 7.1$ for men and women respectively $(\mathrm{P}<0.001)$. While a low muscle mass was diagnosed in 45 patients $(42.5 \%)$, the median graft volume-to-recipient standard liver volume percent (GV/SLV\%) and graft-to-recipient weight ratio (GRWR) were $40 \%(36-47 \%)$ and 0.78 (0.66-0.92) respectively. Interestingly, pre-LT SMI showed a significant correlation with the postoperative GRR in man but not in women $(\mathrm{P}=0.04)$. Overall, a low GRR was significantly associated in patients with sarcopenia. When fitting a multivariable model with GV/SLV\%, donor age, gender, pre-LT SMI, and SMIv\%, pre-LT SMI remained 
statistically associated with the GRR after LDLT. The authors conclude that during the anabolic process of liver regeneration, male recipients are rather affected from muscle loss while female patients experience fat depletion. Other factors, influencing GRR were the recipient's severity of illness preoperatively and the capability of the stress caused by the transplantation as a major surgical procedure, the immunosuppression and the impact of shear effect caused by perfusion after transplantation (5).

Sarcopenia and malnutrition in recipients before LT are well known predictors of morbidity and mortality (6). While the prognostic value of muscle quality (skeletal muscle density and myosteatosis) in comparison to muscle quantity (SMM, as the morphological aspect of sarcopenia) was recently investigated by our group in a cohort of whole-graft LT $(1,2)$, its significance for LDLT remains to be determined. Myosteatosis describes pathological intramuscular adipose fat tissue deposition caused by metabolic dysregulation in patients with ESLD. The relevance of myosteatosis on graft regeneration may be linked to a muscle-to-liver-cross talking, with increased secretion of pro-inflammatory cytokines, adipocytokines and lowers the concentrations of myokines (7). This imbalance may in turn lead to systemic inflammation with an unfavorable immune response and restrained graft regeneration or even early allograft dysfunction (EAD) (2).

The assessment of the recipients $\mathrm{BC}$ - and nutritional status are not displayed in the current Model for EndStage Liver Disease (MELD) LT-scoring system. Even though, the clinical estimation of $\mathrm{BC}$ and the assessment of their physical strength using conventional parameters (body weight, waist circumference, BMI, ability to walk or physical activity, and handgrip) is usually a difficult task to accomplish in these waiting-list patients, the present work from Pravisani et al. and others emphasize the relevance of BC-assessment in this LT context. Therefore, current and future clinical trials should also incorporate therapeutic interventions such as the monitoring of dietary intake, protein or branched-chain amino acid supplementation, prehabilitation, physical exercise, and/or pharmacotherapy.

\section{Acknowledgments}

Funding: None.

\section{Footnote}

Provenance and Peer Review: This article was commissioned by the editorial office of Hepatobiliary Surgery and Nutrition. The article did not undergo external peer review.

Conflicts of Interest: All authors have completed the ICMJE uniform disclosure form (available at https://hbsn. amegroups.com/article/view/10.21037/hbsn-21-202/coif). The authors have no conflicts of interest to declare.

Etbical Statement: The authors are accountable for all aspects of the work in ensuring that questions related to the accuracy or integrity of any part of the work are appropriately investigated and resolved.

Open Access Statement: This is an Open Access article distributed in accordance with the Creative Commons Attribution-NonCommercial-NoDerivs 4.0 International License (CC BY-NC-ND 4.0), which permits the noncommercial replication and distribution of the article with the strict proviso that no changes or edits are made and the original work is properly cited (including links to both the formal publication through the relevant DOI and the license). See: https://creativecommons.org/licenses/by-nc-nd/4.0/.

\section{References}

1. Czigany Z, Kramp W, Bednarsch J, et al. Myosteatosis to predict inferior perioperative outcome in patients undergoing orthotopic liver transplantation. Am J Transplant 2020;20:493-503.

2. Czigany Z, Kramp W, Lurje I, et al. The role of recipient myosteatosis in graft and patient survival after deceased donor liver transplantation. J Cachexia Sarcopenia Muscle 2021;12:358-67.

3. Czigany Z, Lurje I, Schmelzle M, et al. IschemiaReperfusion Injury in Marginal Liver Grafts and the Role of Hypothermic Machine Perfusion: Molecular Mechanisms and Clinical Implications. J Clin Med 2020;9:846.

4. Czigany Z, Lurje I, Tolba RH, et al. Machine perfusion for liver transplantation in the era of marginal organs-New kids on the block. Liver Int 2019;39:228-49.

5. Pravisani R, Soyama A, Ono S, et al. Is there any correlation between liver graft regeneration and recipient's pretransplant skeletal muscle mass?-a study in extended left lobe graft living-donor liver transplantation. Hepatobiliary Surg Nutr 2020;9:183-94.

6. Kalafateli M, Mantzoukis K, Choi Yau Y, et al. Malnutrition and sarcopenia predict post-liver 
transplantation outcomes independently of the Model for End-stage Liver Disease score. J Cachexia Sarcopenia Muscle 2017;8:113-21.

7. Hamaguchi Y, Kaido T, Okumura S, et al. Proposal for new selection criteria considering pre-transplant muscularity and visceral adiposity in living donor liver transplantation. J Cachexia Sarcopenia Muscle 2018;9:246-54.

Cite this article as: Uluk D, Pratschke J, Lurje G. Influence of skeletal muscle mass on graft regeneration after living-donor liver transplantation. HepatoBiliary Surg Nutr 2021;10(4):564566. doi: 10.21037/hbsn-21-202 